\title{
Fuzzy Frontiers: A Performative Materialization of Intentionality
}

\author{
Gaelyn Aguilar, Gustavo Aguilar
}

Play Sound Track 1 (0:00-2:06). ${ }^{1}$

Borders and borderlands have long captured the attention of scholars and critically informed artists who rightfully regard these interstitial environs as frontiers of identity, where states are at the extremity of their power to shape the quotidian lives of the people who actually inhabit these fuzzy frontiers. Borderlands are often perceived by nonborderlanders as marked by various oppositional forces-forces which, once in circulation, have the symbolic and material effect of feeding into binary logic (a system that almost always serves the purpose of dodging real complexity and silencing dissonance), and titillating the headstrong rush of politicians and policy makers who feel pressured to keep inimical forces at bay. To declare a war (...on drugs, on "illegals," on terrorism). To conflate the issues. To grant safe passage to capital, and not the people displaced by its mobility. Build a wall that cuts through this spot, this stain, this smudge. Yet how do we catalyze attention to other lines of desire, ones in which "our destinies and aspirations are in one another's hands" (Gómez-Peña 70)? How can we shift out of the paradigm in which difference has no power, and into one where difference fosters the kind of critical multiculturalism that is necessary to achieve social justice? $^{2}$

In existence since 2006, Tug-a free-range collective that we co-direct/facilitate and that serves as a platform for addressing issues of social and cultural transformation (www.tugcollective.org) - has wondered about these things while wandering along the "NAFTA Corridor," that enormous crack in the pavement through which so many of the global processes (that put people, ideas, media, technologies, and capital into motion) have been flowing since the ink dried on the North American Free Trade Agreement in 1994. Slipping into the crack, and driven by process, Tug has explored the social navigation of lived environments in Michoacán (one of México's five feeder states for migration to the United States) by walking, talking with people, recording sound, creating an interactive sound map, taking photographs, exhibiting art and poetry, creating music, and developing something akin to what Suzi Gablik would characterize as "a fieldlike conception of the self that includes more of the environment-a selfhood that releases us into a sense of our radical relatedness" (Gablik 85), even as we recognize difference. The collective has worked as a sound incubator ${ }^{3}$ in Windsor, Ontario, Canada, recording sound levels coming off the Ambassador Bridge - the busiest border crossing for international trade in North America-and coming up with ways to mitigate that sound through the creation of a pocket park. ${ }^{4}$ More recently, Tug organized the 2011 Borderlands Symposium at the University of Maine at Farmington that brought together interdisciplinary creative thinkers and activists from along the US-México/US-Canadian borders with community organizers in the state of Maine (a forgotten Borderland of the American Northeast) who work with migrant laborers on health and education concerns. ${ }^{5}$

The projects that have engaged the collective over the years come from disparate moments and geographic locations, but there are several constants to each that both emanate from our foundational gesture of approaching culturally-inflected places and spaces as sites of contestation, collaboration, and transformation, and orbit around one another as a continuum of connective tissues. ${ }^{6}$ For starters, although we form the core of Tug, we do not conceive of (or carry out) projects in isolation. In other words, wherever it goes and whatever it might do, Tug is always two plus whomever we can recruit with the help of our respective local collaborators, which have included art/performance practitioners, small galleries, universities, social workers, activists, and people who would self-identify as "ordinary citizens."

Second, we have approached our projects in such a way that we are always trying to pay attention to what Arjun Appadurai has called "globalization from below"-a kind of "grassroots globalization" in which people are able to respond to and challenge global flows "independently of the actions of corporate capital and the nation-state system" (3). If taken too literally, Appadurai's "globalization from below" suggests that it is possible to recuperate a social space that is independent of neoliberalism and the global marketplace. Our reading (and, thus, our materialization) of Appadurai, however, oscillates between his urgent call for tapping into the research imagination and to connecting to what is actually going on in various "zones of exclusion," Mary Louise Pratt's elegant term for those social spaces "where life is being lived otherwise. Where identities cannot be organized around salaried work, consumption, or personal projects like upward mobility, life has to be lived, organized, and understood by other means. People generate ways of life, values, knowledges and wisdoms, pleasures, meanings, hopes, forms of transcendence relatively independent of the ideologies of the market" (Pratt 4).

The third constant (and this is related to why we refer to Tug as "free-range") is that we consider the collective to be a laboratory for interdisciplinary creative exploration. That is to say, we try to create spaces where there is no disciplinary hierarchy. The fourth constant (which is closely aligned with the third) is that we call upon the theory and 
methodology of improvisation, loosely defined in a musicking sense, because we believe that there is a great deal of value inherent in the way that improvisation presents itself as a non-hierarchical (ideally), process-oriented practice, that claims no victories and is rooted in a "listening self" (Gablik 82). At this point, the reader might intuit that we mean to operationalize distinct meanings of improvisation, perhaps that of a verb (e.g. process) and that of a noun (e.g. a thing or object such as a performance). What we are trying to proclaim into existence, however, is something more akin to what agglutinated languages such as Inuit or Saami express_-"moments of becoming and activity" (Edmund Carpenter qtd. in Rodaway 112). Such moments will always be slippery since they necessitate "bring[ing] things/action (nouns/verbs) into being as [language] goes along" (Edmund Carpenter qtd. in Rodaway 112-113). This slipperiness is also a stance against what Henry Giroux refers to as the "politics of clarity"-an homogenizing tendency toward cleansing knowledge "of complex discourses or oppositional insights" (qtd. in Pollack 77). If our work is going to proceed non-hierarchically, then we must take care to infuse all aspects of it with plurality.

In summary, through the work of Tug, we are interested in investigating, contemplating, processing, and communicating how individuals_-bodies that must appear to one another, for politics to emerge (Butler 2)-are able to exercise their agency in responding to and challenging global flows, and how improvisation-as a stance of historically situated "perpetual becoming" (Lewis xl), "a strategy for social and political intervention" (Heble 79), or even a condition "somewhere between being and nothingness" where one neither refuses an identity nor provides or expects "necessary and sufficient predicates" to define it (Torres 57)—might move and illuminate this agency.

Our work (e.g. the collaborations we initiate vis-à-vis Tug) is inherently cumulative; everything we do takes on a particular, significant salience that forms a research continuum of what George Lewis would call "intellectual flows." That being said, we are at the beginning stages of integrating our work over the past five years into a large-scale, interdisciplinary, performative research project entitled, Borders, Corridors, and Lines of Desire: Outposts of Improvisation on the Unmarked. The connective tissues for this project can be traced to 2006 when, with the help of over 50 citizen volunteers from the South Texas bordertown of Brownsville, we completed Ah, Raza! The Making of an American Artist, a 43-minute "momentary live installation" that speaks to the recuperation and expansion of what it means to be a US-American of Mexican descent along the border. Presented in such a way that, as it goes inward to deal with the personal histories of its subject, it ends up expanding outward to deal with other histories, Ah, Raza! intertwines various sonic environments with an intersection of a multiplicity of gazes: pre-recorded, pre-composed (fully notated) musical elements; present-composed (improvised) musical elements; a soundscape choreography of narratives; childhood snapshots; still portraits of the city of Brownsville and its residents caught in a moment of their lives; visual ethnographies; and video portraits of Brownsville residents, morphing from one face to the next, youngest to oldest. All along, it has been our goal to call upon Ah, Raza! (vis-à-vis multiple performances of it) in order to encourage dialogue and action that will seed and extend deeper readings of these themes of recuperation and expansion, given the larger social, political, and economic webs of power and significance in which people along the US/México border are immersed.

\section{How will we proceed?}

We have identified (but not in a totalizing or finalizing way) several "outposts of improvisation" that will entail mobilizing, in a kind of "space-clearing gesture," people throughout Brownsville to engage in a series of openstructured workshops, whose outcomes will become the sites and sounds, the jottings, the field notes, the scenes, the asides, the commentaries, and the memos of our critical performative approach to searching for gaps in the order of things - to seeking out gaps, that is, in which there might be "room for maneuver" (Ross Chambers qtd. in Stewart 3). To refer to these open-structured workshops as "outposts of improvisation" might seem odd, given the extent to which improvisation is inherent in our everyday existence (e.g. it is not contained, but is all around us) and given the historical, political, and cultural specificity that gets drawn when one evokes the dictionary definitions of "outpost" as "a small military camp or position at some distance from the main army" or "a remote part of a country or empire" ("Outpost"). The fact is, South Texas is full of these evocations, which began long before Manifest Destiny-the nineteenth-century Euro-American colonial enterprise in which "White Americans marched across the North American continent and took it" (Spickard 129)_left its mark on the region, and that continue into present-day concerns about Homeland Security. While a South Texas borderlander can never escape the resonance and residue of these embodied practices, s/he can still negotiate some release (whether it be symbolic and/or material) through the very thing that improvisation can do-which, to borrow from Diana Taylor's thoughts about the multi-valianceness of performance studies, is to "break into a structure and find other options for it" (Kirshenblatt-Gimblett).

We would like to use the remainder of this essay to telescope in on the inner workings of one of these possible "outposts of improvisation" (open-structured workshops)—one that we are calling "Focusing on the Fuzzy." Before unpacking the details, however, we want to expose the seed of this outpost before it began to explode rhizomatically. 


\section{Where Things Begin}

In 1996, Gustavo was sitting in on a course at the California Institute of the Arts being taught by two distinguished US-American artists. The title of the course- "The Making of an American Artist"-intrigued him immensely, as did the promise that the class was going to be an opportunity for participants to understand how US-American history and culture manifest themselves through the art of those born and raised in the United States.

Gustavo was born and raised in the United States-in Brownsville, Texas to be exact. Brownsville is a town where heteromorphic individuals such as Gustavo have been in the numeric majority for well over 150 years-ever since the Treaty of Guadalupe Hidalgo ended the Mexican-American War (or what might be referred to in México as "The First US Intervention in México") and violently extended the borders of the United States westward and southward. With the stroke of a pen, without moving, over 100,000 people became foreigners in their native land. They became, along with their offspring, an "alter-Native culture [...] both indigenous and alien to the United States" (Gaspar de Alba 15).

Yet, as Gustavo sat listening to a lecture about all of the cultural icons who presumably were to have impacted and influenced him as an US-American artist, he felt a rush of alienation when he realized that, although he knew who these icons were and could, in fact, trace some affinity to them, there was a significant part of his experience and upbringing that was completely absent from the discussion. It was, as the poet and essayist Adrienne Rich would have called it, a "moment of psychic disequilibrium":

When those who have the power to name and to socially construct reality choose not to see you or hear you, whether you are dark-skinned, old, disabled, female, or speak with a different accent or dialect than theirs, when someone with the authority of a teacher, say, describes the world and you are not in it, there is a moment of psychic disequilibrium, as if you looked into a mirror and saw nothing (Rich 199).

Invisibility is a dangerous condition. Ten years were to pass between Gustavo's moment of disequilibrium and the creation of Ah, Raza! The Making of an American Artist. During that span of time, improvisation became, for both of us in our respective endeavors, a fieldwork methodology both for performing what José Limón would call "an archaeology of subjugated knowledges and practices" (Limón 125) and for developing contingent, unpredictable, and productive open-system maps-a kind of Deleuzian cartography_that could inspire a "politics of becoming-otherthan-what-one-now-is" (Razsa and Krunik 241) by "mak[ing] space for possibility, what could be, as a crucial dimension of what is or what was" (Biehl and Locke 323). That is, improvisation became a methodology for unearthing an "alter-Native" but critical understanding that one could, through improvisation, learn to listen for resonance in multiple sources of knowledge and practice without the antagonistic imperative to choose sides.

\section{Resisting the Void}

The kind of erasure referred to above is not uncommon in the United States, a country where, to ironic effect, notions of pluralism and multiculturalism so often define what it means to be an American. Pluralism is a tricky concept, however. The Dictionary of Anthropology defines plural societies as "those that contain multiple ethnic populations within a shared economy and centralized political order" (Barfield 362). It sounds all warm and fuzzy, and it certainly plays into the filial piety that US-Americans have to those soaringly poetic visions of themselves. The truth of the matter, however, is that one of the critical features of all plural societies is the presence of ethnic hegemony (one ethnic group dominating the others), which is to say that in the United States, pluralism, like other narratives of national self-celebration, is built on what Paul Spickard (5) describes as "an interlocking set of unexamined assumptions about how various racial and ethnic groups have in fact functioned in relationship to each other in American history." One is left wondering, then, what sort of pluralism actually exists in the United States given the context of almost 400 years of Anglo-conformity and Normative Whiteness.

Multiculturalism—another, perhaps, even warmer and fuzzier paradigm—similarly buckles under scrutiny. Borne out of the shifting faultlines of the US-American civil rights movements in the 1960s and 1970s, multiculturalism (in theory and practice) has worked for those it was meant to protect. Cultural systems, no matter how vigilant we are to problematize the very concept of culture for incarcerating people spatially and temporally, can be properly considered "extra-somatic systems of survival" (Peek 16). In a recent interview, the San Francisco-based performance artist Guillermo Goméz-Peña explains, however, that when multiculturalism was at its peak in the later 1980s, "we realized that something was fundamentally wrong with the multicultural premise. Our job was to perform our authenticity so that the self-proclaimed center, the mainstream, could understand us and accept us on its own terms. That was, fundamentally, a neo-colonial model" (Banks). Neo-colonial, indeed, for "[t]he bottom line of multiculturalism" in the United States (which Gaspar de Alba defines broadly as "close encounters of the Third World kind between the dominant culture and 'aliens'-a category which includes immigrants of both the documented and undocumented varieties as well as citizens and residents who for generations have grappled with racial, ethnic, and cultural 
bigotry")-is difference, "and difference has never had power in [the United States]. Difference gets melted down, exoticized, stereotyped, invisibilized" (Gaspar de Alba 19). ${ }^{9}$

\section{Focusing on the Fuzzy}

"Focusing on the Fuzzy" will play itself out as a four-movement "outpost of improvisation" (think musical form) which, perhaps like Kathleen Stewart's ethnographic work in the US Appalachian coal-mining region of southwestern West Virginia, will "approach the clash of epistemologies [...] and to use that clash to repeatedly re-open a gap [...] so that we can imagine culture as a process constituted in use and therefore likely to be tense, contradictory, dialectical, dialogic, texted, textured, both practical and imaginary, and in-filled with desire" (Stewart 5).

\section{Movement I: A performance of Ah, Raza! The Making of an American Artist.}

Movement II: An immediate sharing of experience, perception, reception, and resonance; a "free-zone for intercultural dialogue" (Gómez-Peña 99) about how we construct difference. Do we push it away? Do we embrace it? Or do we let it oscillate? What does it mean to be an American? Who belongs? Who doesn't? Who deserves? Who doesn't? Do we build a wall? Or do we knock it down?

Movement III: "Seeing what happens if we change the condition of something," as Vito Acconci might put it (Acconci). ${ }^{10}$ Seeing what happens, that is, were we to work as an improvisational ensemble to collaboratively write an open-structured paper. Utilizing the conceptual impulse and structure of a game created by David Elliott called, This Game Makes Me Feel Like a Machine ${ }^{11}$ we will function as a Human Computer, in which previously-composed excerpts dealing with questions raised in Movement II will become the catalyst for collectively responding (e.g. computationally and subjectively processing) in a deterritorialized way.

One of the reasons we are drawn to Elliott's game is that it reinforces a particularly apt metaphor for our processdriven approach to deterritorialization-that of a desire line. A desire line is a path; a path created by movement. In nature, the erosions created by both animal and human footfall can create an understanding of safe paths and social behavior, a cleared pathway or "well-worn ribbon of dirt" down which other travelers are encouraged to follow. Many of the city streets we travel on today began as desire lines, social trails that the futuristic denizens of the past studied and used to propose the transit routes around which the musculature of the urban environment could be built.

Today's urban planners look to changing demographics (e.g. shifting employment patterns and projected increases in population) as a way to anticipate (and control, contain, and exploit?) future lines of desire. But desire lines are also (like improvisation) about yearning or inventing one's path "without being inhibited by certain prescribed forms" (Smith 11). Think of the impulse that many of us might have to cut across a fresh patch of grass rather than remain on such a prescribed form as a concrete sidewalk. In a sense, desire lines are an ultimate expression of natural purpose. Might this mean, Carl Myhill (1) argues, "[that] the optimal way to design pathways [...] is to not design them at all"? By extension, we wonder, could we take this approach to learning (e.g. to investigating, contemplating, processing, and communicating)? "Would mayhem ensue," asks Marica Sevelj, "if we just planted seeds and waited to see what happened?"12

Movement IV: A kind of thought experiment. When we speak of improvisation as having been (or continuing to be) our will to knowledge and meaning, or when we put upon improvisation the responsibility of encouraging dialogue and action, we are engendering improvisation with the ability of placing ourselves and others into a state of being and becoming (something that we refer to as reflective thinking) that offers us the opportunity to create and express ideas while also allowing our resulting creations to "include the entire spectrum of space and cycle of time" (Smith 9). How can one claim all of one's personal histories without locking oneself into fixed models that play up to the contours of iconic images? How can one be what one is and not "do the oppressor's work by building one's own closet" (Rich 199)?

\section{Stacked Time}

California Institute of the Arts: Spring Music Festival, 1998.

George Lewis_improviser, composer, performer, and computer/installation artist-took to the stage, seemingly unfazed by the roar of applause directed at him, a man who has been engaged in the act of creating for much of his adult life. With members of his Improvisers Ensemble already seated before him, Lewis placed onto his music stand a tattered score that had been glued to a large paper bag, and began mumbling to his collaborators on stage. They smiled, prepared themselves, and seemed to take nonchalant notice as Lewis gave them a verbal cue. "Get ready for what's not on the page," Lewis warned. With that, Collage began. 
One could tell that Lewis knew his musicians; he had studied them carefully, knew their temperaments, limitations and strengths, and he knew exactly how, and when, to draw out their voices. One moment, he would face the horn section with his lips pursed and his right arm punching at the air. The next moment he would whip himself around toward the woodwind players, raise his arms and then start running scales furiously with his fingers. At times, his whole body would gesture, do this with your sound!

As the apparent cacophony mounted, Lewis' body would go still. Head bowed, he would walk away, hands in pocket, as if he knew that the resonance between his voice and the voices of his collaborators had reached the point where there was a balance between the improvising self, who allows a lifetime of experience and conditioning to wash over as snap decisions are made and then sent out into the wind, and the realization that it is not the improvisation itself that matters, but how the very act of improvising inherently communicates to us that our experiences and negotiations are inextricably involved with others.

Play Sound Track $2(0: 00-1: 40){ }^{13}$

We see borders and they look like strong lines of demarcation, but once down on the ground, we realize that borders are fuzzy frontiers; we realize that "What the map cuts up, the story cuts across" (de Certeau 129). By "Focusing on the Fuzzy," we are hoping to explore how this spot, this stain, this smudge-this part of the US/ México border-in all of its manifestations, matters for people living along it, within it, and against it. We want to set out the score, trust one another, and wait for the feedback loop to occur.

\section{Notes}

${ }^{1}$ Sound Track 1 is a collage created from various tracks from Destinations, a CD recording by the Gustavo Aguilar Get Libre Collective, and "Me Desnudo," the opening movement of Ah, Raza!: The Making of an American Artist, a momentary live installation that is addressed throughout this essay.

${ }^{2}$ Critical multiculturalism, which has many advocates (Barry Kanpol, Paulo Freire, Henry Giroux, bell hooks, Stephen May, Peter McLaren, and Christine Sleeter, to name a few), is an approach to education that takes seriously the imperatives of living in a multicultural/multi-social race democracy. Against standardization (standardization being neo-liberalism's way of containing and diffusing oppositionality), critical multiculturalism is inherently anti-racist in that it seeks to prevent new forms of nativism by challenging narrow ideological parameters.

${ }^{3}$ In this case, we were using the term "sound incubator" to suggest a space where both noise, and what some would call our evolutionary pursuit of silence, facilitated our understanding of how sound affects human ecology.

${ }^{4}$ Ostensibly a small patch of landscaped nature built in an urban setting, a pocket park plays with our cross-sensory perception of noise by creating what George Prochnik would call "an attractive barrier that enhances the sense of silence" (Prochnik 221). Our pocket park remains at the prototype stage.

${ }^{5}$ We want to thank our colleague, Sabine Klein, for making us aware of the colonial borderlands of the American Northeast, and the extent to which the historical relationships between the Wabanaki Confederacy and the French, English, and Dutch settlers continue to resonate in the state of Maine.

${ }^{6}$ For an elegant, visual representation of what these connective tissues might look like in relationship to one another, see Casey Reas' online Path Prints, a series of six prints "documenting the movement of synthetic neural systems."

${ }^{7}$ Personal communication.

${ }^{8}$ We came across this phrase while listening to Jack Halberstam give a talk on "The Wild: Performing Anarchy" at the Hemispheric Institute of Performance and Politics conference/ gathering, Cities/Bodies/Action-The Politics of Passion in the Americas, in São Paulo, Brazil in January 2013. Halberstam was, himself, taking a cue from James Scott's Two Cheers for Anarchism.

${ }^{9}$ There are many examples of how these two paradigms—-pluralism and multiculturalism—obfuscate and/or incarcerate alter-Native ways of being and becoming. In his introduction to an interview with the writer Arturo Islas, Hector Torres recounts what happened when Islas (who was born and raised in El Paso, Texas-another border town) tried and failed to publish his first novel, The Rain God, with a New York City publishing house. "The narrow view of Chicano/Chicana cultures and linguistic codes that these agents of literary value [held, led] them to reduce 
The Rain God to the bearer of an ethnic cultural message," a message that Islas apparently failed to conform to by (among other things) not stereotyping his characters as Chicano or Chicana (Torres 56). More recently, in a documentary entitled "Brown is the New Green," George Lopez (a comedian who headlined his own situation comedy on network television in the United States for many years) talks about being in meetings where he wasn't particularly happy with how studio executives were asking him to portray Americans of Latino descent. "And the Chicano in me would say 'I'm leaving.' But when you leave, you're out. So I made myself stay” (qtd. in Rodriguez).

${ }^{10}$ In this recent video interview conducted by Rehana Zaman, and posted on the Internet by the Wooster Group, Acconci is asked where he thinks art is heading. "I hope it is headed to its own dissolution," he responds candidly: "I don't think there's any reason any more for art to exist as a separate field. Art is, rather, a kind of methodology, a kind of mode of operation, a kind of way of doing things that really is a part of any field. Art is what happens if we change the condition of something."

${ }^{11}$ We first came across Elliott's work while exploring the homepage of Future Farmers, an international collective of artists. This Game Makes Me Feel Like a Machine is a game that comes from a collaboration that Elliott did with Future Farmers entitled "The Reverse Ark: The Flotsam and the Jetsam." Details are available at: http://www.futurefarmers.com/reverseark/writing.html.

${ }^{12}$ See http://marica.ako.net.nz/2005/08/14/desire-lines-and-maps/

${ }^{13}$ Sound Track 2 is a collage created from various tracks from Destinations, a CD recording by the Gustavo Aguilar Get Libre Collective, and a processed recording of Gaelyn Aguilar reading snippets from "Thinking Freedom: The Balance Between Autonomy and Care," a co-written, performative essay that we co-delivered to a panel on The Art of Improvisation at the annual meeting of the Association for Social Anthropologists in New Delhi, India in April 2012.

\section{Works Cited}

Acconci, Vito. Interview by Rehana Zaman. The Wooster Group, YouTube, 7 July 2011. http://www.youtube.com/watch?v=Z5VpFRUMBhY. Web. 4 May 2013.

Appadurai, Arjun. “Grassroots Globalization and the Research Imagination.” Public Culture 12 (2000): 1-19. Print.

Banks, Gabrielle. "Culture-Trafficking for the 21st Century: An Interview with Guillermo Gomez-Pena." Colorlines. Web. 4 May 2013. http://colorlines.com/archives/2003/06/culturetracfficking for the 21st century.html.

Barfield, Thomas, ed. The Dictionary of Anthropology. Malden, MA: Blackwell, 1997. Print.

Biehl, João and Peter Locke. "Deleuze and the Anthropology of Becoming." Current Anthropology 51.3 (2010): $317-$ 351. Print.

Butler, Judith. "Bodies in Alliance and the Politics of the Street." Institut Européen pour des Politiques en Devenir. 27 Nov. 2012. Web. 9 Jan. 2013. http://eipcp.net/transversal/1011/butler/en.

de Certeau, Michel. The Practice of Everyday Life. Berkeley: University of California Press, 1984. Print.

Gablik, Suzi. "Connective Aesthetics: Art after Individualism." Mapping the Terrain: New Genre Public Art. Editor Suzanne Lacy. San Francisco: Bay Press, 1994. Print.

Gaspar de Alba, Alicia. Chicano Art: Inside/Outside the Master's House. Austin: University of Texas Press, 1998. Print.

Gómez-Peña, Guillermo. The New Borderland: Prophecies, Poems \& Loqueras for the End of the Century. San Francisco: City Lights, 1996. Print.

Gustavo Aguilar Get Libre Collective. Destinations. Circumvention Music, 2003. CD.

Heble, Ajay. Landing on the Wrong Note: Jazz, Dissonance and Critical Practice. New York: Routledge, 2000. Print. 
Kirshenblatt-Gimblett, Barbara. "Interview with Diana Taylor: What is Performance Studies? (2002)." Hemispheric Institute Digital Video Library. Web. 29 Sept. 2012. http://hemisphericinstitute.org/hemi/en/hidvl/hidvl-intwips/item/1350-wips-dtaylor.

Lewis, George. A Power Stronger Than Itself: The AACM and American Experimental Music. Chicago: University of Chicago Press, 2008. Print.

Limón, José. Dancing With the Devil: Society and Cultural Poetics in Mexican-American South Texas. Madison: The University of Wisconsin Press, 1994. Print.

Myhill, Carl. "Commercial Success by Looking for Desire Lines." 2004. .1 Apr. 2013 Available in PDF form at: http://www.scribd.com/doc/7898293/Commercial-Success-by-Looking-for-Desire-Lines-by-Carl-Myhill.

"Outpost." Oxford Dictionaries. Web. 26 Apr. 2013. http://oxforddictionaries.com/us/definition/american english/outpost.

Peek, Philip. "Re-Sounding Silences." Sound. Ed. P. Kruth and H. Stobard. Cambridge: Cambridge University Press, 2007. Print.

Pollock, Della. "Performing Writing." The Ends of Performance. Ed. Peggy Phelan and Jill Lane. New York: New York University Press, 1998. Print.

Pratt, Mary Louise. "Planetary Longings: Sitting in the Light of the Great Solar TV." World Writing: Poetics, Ethics, Globalization. Ed. Mary Gallagher. Toronto: University of Toronto Press, 2008. Print. Available in PDF form at: https://www.google.com/search?q=planetary+longings\&ie=utf-8\&oe=utf-8\&aq=t\&rls=org.mozilla:enUS:official\&client=firefox-a.

Prochnik, George. In Pursuit of Silence: Listening for Meaning in a World of Noise. New York: Doubleday, 2010. Print.

Razsa, Maple and Andrej Kurnik. "The Occupy Movement in Žižek's Hometown: Direct Democracy and a Politics of Becoming." American Ethnologist 39.2 (2012): 238-258.

Reas, Casey. Path Prints. Works/Path Prints. Personal Website. 4 May 2013. http://reas.com/iperimage.php?section=works\&work=path $\mathrm{p}$.

Rich, Adrienne. Blood, Bread, and Poetry: Selected Prose 1979-1985. New York: W.W. Norton \& Company, 1986. Print.

Rodaway, Paul. Sensuous Geographies: Bodies, Sense and Place. London: Routledge, 1994. Print.

Rodriguez, Phillip. "Brown is the New Green: George Lopez and the American Dream.” PBS Home Video, 2007. DVD.

Scott, James. Two Cheers for Anarchism: Six Easy Pieces on Autonomy, Dignity, and Meaningful Work and Play. Princeton, NJ: Princeton University Press, 2012. Print.

Smith, Wadada Leo. Notes (8 Pieces) source a new world music: Creative music. Self published, 1973.Print.

Spickard, Paul. Almost All Aliens: Immigration, Race, and Colonialism in American History and Identity. New York: Routledge, 2007. Print.

Stewart, Kathleen. A Space on the Side of the Road: Cultural Poetics in an "Other" America. Princeton: Princeton University Press, 1996. Print.

Torres, Hector. Conversations with Contemporary Chicana and Chicano Writers. Albuquerque: University of New Mexico Press, 2007. Print. 